\title{
ANALISIS GEOGRAPHICALLY WEIGHTED REGRESSION (GWR) PADA KASUS PNEUMONIA BALITA DI PROVINSI JAWA BARAT
}

\author{
Meila Nadya, Widyanti Rahayu, Vera Maya Santi \\ Jurusan Matematika FMIPA UNJ \\ meylanadya1@gmail.com
}

\begin{abstract}
Abstrak
Pneumonia adalah salah satu penyakit Infeksi Saluran Pernapasan Akut (ISPA) yang disebabkan oleh bakteri atau virus. Di Indonesia, pneumonia merupakan penyebab kematian balita tertinggi kedua setelah diare. Kasus pneumonia pada balita terbanyak yang ditemukan di Indonesia adalah di provinsi Jawa Barat. Untuk mengatasi pneumonia balita perlu dianalisis faktor penyebab pneumonia balita. Salah satu cara untuk menganalisis faktor tersebut adalah dengan menggunakan analisis Geographically Weighted Regression (GWR). Analisis GWR merupakan pengembangan dari analisis regresi linier berganda yang dapat mengatasi keragaman wilayah/heterogenitas spasial sehingga menghasilkan model dan pendugaan parameter berbeda untuk setiap wilayah amatan. Hasil analisis GWR dengan menggunakan pembobot spasial \extit\{Fixed Kernel Gaussian\} menunjukkan bahwa model GWR lebih baik daripada model regresi linier berganda. Hal ini berdasarkan nilai $R^{2}$, nilai $R^{2}$ dari model GWR (88.34\%) lebih besar dari $R^{2}$ dari model regresi linier berganda (71.86\%). Sementara, Jumlah Kuadrat Galat (JKG) untuk model GWR diperoleh 3.031 lebih kecil bila dibandingkan dengan nilai JKG dari regresi linier berganda yang sebesar 7.317. Secara umum, terdapat tiga faktor yang berpengaruh signifikan terhadap kasus pneumonia balita di provinsi Jawa Barat tahun 2014 yaitu jumlah balita gizi buruk, persentase bayi yang diimunisasi dasar lengkap dan jumlah puskesmas.
\end{abstract}

Kata kunci: pneumonia balita, Jawa Barat, Fixed Kernel Gaussian, model GWR, heterogenitas spasial.

\section{PENDAHULUAN}

\section{A. Latar Belakang}

Pneumonia adalah penyakit infeksi menular yang disebabkan oleh kuman Pneumococcus, Staphylococcus, Streptococcus dan virus. Pneumonia merupakan penyakit kedua setelah diare yang menyebabkan kematian pada anak usia dibawah 5 tahun (balita) (Dinkes, 2015). Di Indonesia, salah satu provinsi yang turut menyumbang penyakit pneumonia balita tertinggi adalah provinsi Jawa Barat.

Salah satu upaya yang dapat dilakukan untuk menganalisis faktor-faktor penyebab penyakit pneumonia pada balita di provinsi Jawa Barat adalah dengan menggunakan analisis regresi linier berganda. Salah satu metode statistika yang dapat digunakan untuk menganalisis kasus gizi buruk pada anak balita adalah analisis regresi. Namun analisis regresi linier berganda menghasilkan nilai penduga yang bersifat global. Pada kenyatannya, seringkali analisis yang menghasilkan model berbasis lokal kewilayahan sangat diperlukan karena bisa hasil dari kasus yang diteliti beragam dari satu wilayah ke wilayah lain yang disebut heterogenitas spasial. Model yang dapat mengatasi masalah heterogenitas spasial adalah Geographically Weighted Regression (GWR) (Fortheringham et al. 2002). Model GWR adalah model yang digunakan untuk menganalisis data spasial yang menghasilkan penduga parameter yang bersifat lokal untuk setiap titik/lokasi dimana data tersebut dikumpulkan (Fortheringham et al. 2002).

\section{B. Perumusan Masalah}

Perumusan masalah yang dikaji adalah sebagai berikut:

1. Bagaimana hasil model GWR kasus pneumonia pada balita provinsi Jawa Barat?

2. Apakah model GWR adalah model yang terbaik untuk memodelkan kasus pneumonia pada balita di provinsi Jawa Barat jika dibandingkan dengan model regresi linier berganda?

3. Faktor-faktor apa yang berpengaruh signifikan terhadap jumlah penderita pneumonia pada balita di provinsi Jawa Barat?

\section{Pembatasan Masalah}

Pembatasan masalah dalam penelitian ini adalah: 
1. Model regresi spasial yang digunakan untuk memodelkan kasus pneumonia pada balita di provinsi Jawa Barat adalah model Geographically Weighted Regression (GWR) karena mempertimbangkan pengaruh heterogenitas spasial.

2. Pembobot yang dihitung menggunakan fungsi kernel.

3. Tipe data spasial yang digunakan adalah data titik.

4. Kasus pneumonia pada balita yang diteliti adalah kasus pneumonia pada balita di provinsi Jawa Barat tahun 2014.

5. Faktor-faktor yang akan diamati antara lain jumlah penduduk miskin, jumlah penderita balita gizi buruk, persentase rumah sehat, persentase bayi yang diberi ASI eksklusif, persentase bayi yang diimunisasi dasar lengkap, persentase bayi dengan Berat Badan Lahir Rendah (BBLR), jumlah puskesmas, dam persentase penduduk yang menggunakan air minum layak..

\section{LANDASAN TEORI}

\section{A. Pneumonia di provinsi Jawa Barat}

Pulau Jawa merupakan pulau yang memiliki jumlah terbanyak di Indonesia yang tentunya memiliki keragaman masalah dalam bidang kesehatan. Salah satu masalah kesehatan yang menjadi perhatian utama pada balita adalah kasus pneumonia. Menurut data yang bersumber dari Kemenkes RI tahun 2015, provinsi Jawa Barat berada di peringkat pertama dari enam provinsi di Pulau Jawa sebesar 197,654 jiwa.

Berdasarkan penelitian Mardjanis Said tahun 2010, faktor yang menyebabkan penyebaran pneumonia balita antara lain:

Faktor Internal

1. Status gizi.

2. Pemberian ASI eksklusif.

3. Imunisasi dasar lengkap.

4. Bayi dengan Berat Badan Lahir Rendah (BBLR).

Faktor Eksternal

1. Tersedianya puskesmas di setiap daerah.

2. Tersedianya air minum yang layak.

3. Kemiskinan.

4. Kondisi rumah

\section{B. Regresi Linier Berganda}

Analisis regresi linier adalah suatu metode statistika yang digunakan untuk menganalisis faktor-faktor yang mempengaruhi variabel yang diteliti. Hasil dari regresi linier berganda adalah berupa model regresi yang menggambarkan hubungan antara lebih dari satu variabel penjelas $(X)$ dengan variabel responnya $(y)$. Model regresi linier dalam bentuk matriks adalah:

dimana:

$$
\boldsymbol{y}=\boldsymbol{X} \boldsymbol{\beta}+\boldsymbol{\varepsilon}
$$

$\boldsymbol{y}$ : vektor variabel respon berukuran $n \times 1$

$\boldsymbol{X}$ : matriks variabel penjelas berukuran $n \times(p+1)$

$\boldsymbol{\beta}$ : vektor parameter berukuran $(p+1) \times 1$

$\varepsilon$ : vektor error berukuran $n \times 1$, diasumsikan $\varepsilon \sim \operatorname{IIDN}\left(0, \sigma^{2}\right)$

$n$ : jumlah amatan

$p:$ jumlah variabel penjelas

\section{Autokorelasi Spasial}

Hukum Tobler I menyatakan bahwa segala sesuatu saling terkait namun sesuatu yang lebih dekat memiliki keterkaitan yang lebih besar. Aspek penting dalam mendefinisikan autokorelasi spasial adalah penentuan hubungan wilayah terdekat (Fischer, 2011) yakni wilayah yang berada di sekitar amatan diduga mempengaruhi wilayah amatan.

Uji Moran's I adalah uji statistik yang digunakan untuk melihat autokorelasi spasial, sehingga dapat dideteksi ada atau tidaknya ketergantungan spasial. Hipotesis yang digunakan adalah:

$H_{0}: I=0$ (tidak ada ketergantungan spasial) 
$H_{1}: I \neq 0$ (ada ketergantungan spasial)

Statistik uji:

dimana:

$$
Z_{\text {hit }}=\frac{I-E(I)}{\sqrt{\operatorname{Var}(I)}}
$$

$I=\frac{n \sum_{i=j}^{n} \sum_{j=1}^{n} W_{i j}^{*}\left(y_{i}-\bar{y}\right)\left(y_{j}-\bar{y}\right)}{\sum_{i=1}^{n} \sum_{j \neq 1}^{n} W_{i j}^{*} \sum_{i=1}^{n}\left(y_{i}-\bar{y}\right)^{2}} \quad ; E(I)=-\frac{1}{(n-1)} \quad ; \operatorname{Var}(I)=\frac{n^{2}(n-1) V_{1}-n(n-1) V_{2}-2 V_{0}^{2}}{(n+1)(n-1)^{2} V_{0}^{2}}$

dengan:

$V_{0}=\sum_{i=1}^{n} \sum_{j \neq i}^{n} W_{i j}^{*} ; V_{1}=\frac{1}{2} \sum_{i=1}^{n} \sum_{j \neq i}^{n}\left(W_{i j}^{*}+W_{j i}^{*}\right)^{2} ; V_{2}=\sum_{k=1}^{n}\left(\sum_{j=1}^{n} W_{k j}^{*}+\sum_{i=1}^{n} W_{i k}^{*}\right)^{2}$

Keterangan:

I = nilai Moran's $I$

$n \quad=$ jumlah amatan

$\bar{y} \quad=$ rata-rata variabel respon dari seluruh lokasi amatan

$W_{i j}^{*} \quad=$ pembobot diperoleh dari queen contiguity

$E(I) \quad=$ nilai rata-rata dari $I$

$\operatorname{Var}(I)=$ nilai variansi dari $I$

$i, j, k=1,2, \ldots, n$

\section{Heterogenitas Spasial}

Heterogenitas spasial disebabkan karena adanya perbedaan karakteristik antar titik lokasi pengamatan. Anselin (1988), menjelaskan bahwa heterogenitas spasial tercermin dari galat dalam pengukuran yang mengakibatkan heteroskedastisitas artinya variansi galat yang dihasilkan tidak konstan.

Uji Breusch-Pagan adalah uji statistik yang dapat mendeteksi heterogenitas spasial. Hipotesis yang digunakan dalam uji Breusch-Pagan adalah

$H_{0}: \sigma_{1}^{2}=\sigma_{2}^{2}=\cdots=\sigma_{n}^{2}=\sigma^{2}$ (tidak terjadi heterogenitas antar wilayah)

$H_{1}$ : Minimal terdapat satu $\sigma_{i}^{2} \neq \sigma^{2}$ (heterogenitas antar wilayah)

Statistik uji:

$$
B P=\frac{1}{2} \boldsymbol{f}^{T} \boldsymbol{Z}\left(\boldsymbol{Z}^{T} \boldsymbol{Z}\right)^{-1} \boldsymbol{Z}^{T} \boldsymbol{f}
$$

dimana, elemen vektor $\boldsymbol{f}$ dirumuskan $f_{i}=\left(\frac{e_{i}^{2}}{\sigma^{2}}-1\right)$ serta,

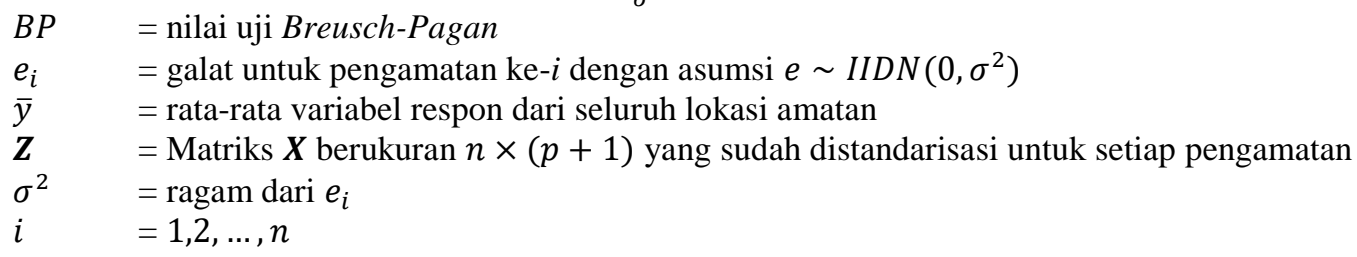

\section{E. Model Geographically Weighted Regression (GWR)}

Model GWR merupakan perkembanan dari analisis regresi linier berganda. Model GWR menghasilkan penduga parameter yang bersifat lokal pada setiap lokasi pengamatan. Secara umum, model GWR dapat ditulis sebagai berikut (Fotheringham et al, 2002).

dimana:

$$
\boldsymbol{Y}=\boldsymbol{X} \boldsymbol{\beta}\left(u_{i}, v_{i}\right)+\boldsymbol{\varepsilon}
$$

$\boldsymbol{Y}=$ vektor variabel respon berukuran $n \times 1$

$\boldsymbol{X}=$ matriks variabel penjelas berukuran $n \times(p+1)$

$\boldsymbol{\beta}\left(u_{i}, v_{i}\right)=$ vektor parameter pada wilayah ke- $i$ berukuran $(p+1) \times 1$

$\boldsymbol{\varepsilon}=$ vektor error berukuran $n \times 1$

$i \quad=1,2, \ldots, n$

$p \quad=$ jumlah variabel penjelas

$u_{i} \quad=$ letak bujur ke- $i$

$v_{i} \quad=$ letak lintang ke- $i$ 


\section{F. Pembobot Spasial}

Dalam menganalisis model yang mempertimbangkan pengaruh spasial diperlukan pembobot spasial dalam perhitungannya. Pembobot spasial menjelaskan letak lokasi amatan yang satu dengan yang lainnya. Menurut Fotheringham et al. (2002), terdapat beberapa fungsi Kernel yan dijadikan sebagai pembobot spasial dalam analisis spasial, antara lain:

Tabel 1. Formula Fungsi Kernel untuk Menghitung Pembobot Spasial

\begin{tabular}{|c|c|c|}
\hline & Kernel Gaussian & Kernel Bi-square \\
\hline Fixed & $w_{i j}=\exp \left[-1 / 2\left(d_{i j} / b\right)^{2}\right]$ & 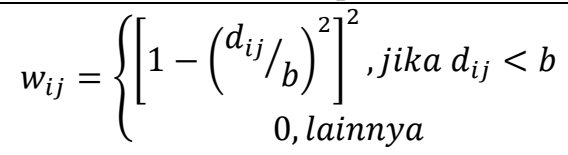 \\
\hline Adaptive & $w_{i j}=\exp \left[-1 / 2\left(d_{i j} / b_{i}\right)^{2}\right]$ & $w_{i j}=\left\{\left[1-\left(\begin{array}{c}d_{i j} / b_{i} \\
b^{2}\end{array}\right]^{2}\right.\right.$, jika $d_{i j}<b_{i}$ \\
\hline
\end{tabular}

Konstanta $b$ yaitu bandwidth yang mengontrol seberapa jauh radius yang masih mempengaruhi lokasi ke- $i . d_{i j}$ adalah jarak euclid antara lokasi ke- $i$ dan ke- $j$ dimana $i, j=1,2, \ldots, n$, yang didefinisikan dengan:

$$
d_{i j}=\sqrt{\left(u_{i}-u_{j}\right)^{2}+\left(v_{i}-v_{j}\right)^{2}}
$$

\section{G. Pemilihan Nilai Bandwidth Optimum}

Pemilihan nilai bandwidth optimum perlu dilakukan karena dapat mempengaruhi hasil penduga pada model. Metode yang dapat digunakan untuk menentukan nilai bandwidth yang optimum adalah dengan meminimumkan nilai Cross Validation (CV). Formula CV adalah sebagai berikut (Fotheringham et al., 2002),

$$
\mathrm{CV}=\sum_{i=1}^{n}\left[y_{i}-\hat{y}_{\neq i}(b)\right]
$$

$\hat{y}_{\neq i}$ adalah nilai dugaan $y_{i}$ pada pengamatan lokasi ke- $i$ dengan bandwidth tertentu dihilangkan dari proses prediksi.

\section{H. Perbandingan Model OLS dengan Model GWR}

Perbandingan model GWR dengan model regresi linier berganda bertujuan untuk mengetahui apakah model GWR atau model regresi linier berganda yang sesuai dalam memodelkan kasus pneumonia balita di provinsi Jawa Barat. Untuk melihat model yang terbaik dapat dilakukan dengan melihat nilai jumlah kuadrat galat terkecil, nilai $R^{2}$ yang terbedar dan nilai Akaike Information Criterion (AIC) yang terkecil (Fotheringham et al. 2002). Perhitungan nilai AIC untuk model GWR dapat dituliskan sebagai berikut (Fotheringham et al. 2002):

dimana:

$$
A I C=2 n \ln (\hat{\sigma})+n \ln (2 \pi)+n+\operatorname{tr}(\boldsymbol{S})
$$

$$
\begin{aligned}
& \pi=3.14 \\
& n \quad=\text { banyak sampel } \\
& \hat{\sigma} \quad=\sqrt{\left(\boldsymbol{y}^{T}(\boldsymbol{I}-\boldsymbol{S})^{T}(\boldsymbol{I}-\boldsymbol{S}) \boldsymbol{y}\right) / n} \\
& \boldsymbol{S} \quad=\left(\boldsymbol{x}_{i}\left[\boldsymbol{X}^{T} \boldsymbol{W}\left(u_{i}, v_{i}\right) \boldsymbol{X}\right]^{-1} \boldsymbol{X}^{T} \boldsymbol{W}\left(u_{i}, v_{i}\right)\right) \\
& \boldsymbol{W}\left(u_{i}, v_{i}\right) \quad=\text { matriks pembobot wilayah amatan ke- } i \text { berukuran }(n \times n) \\
& p \quad \quad \text { jumlah variabel penjelas }
\end{aligned}
$$


III. HASIL DAN PEMBAHASAN

A. Deksripsi Data

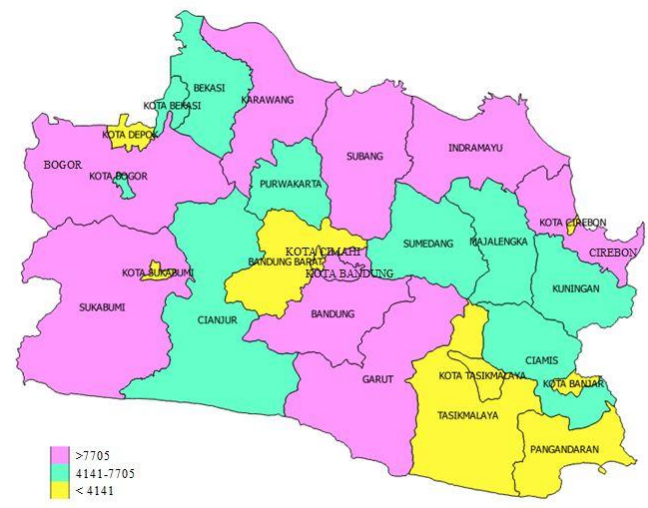

Gambar 1. Distribusi Jumlah Penderita Penumonia Balita

Wilayah yang memiliki jumlah penderita pneumonia balita tertinggi berada di wilayah kabupaten Sukabumi dengan jumlah penderita sebesar 26,756 jiwa sedangkan wilayah dengan jumlah penderita pneumonia balita terendah berada di kabupaten Bandung Barat yakni sebesar 129 jiwa. Berdasarkan Gambar 1, pola penyebaran kasus pneumonia balita di setiap wilayah dari kategori rendah hingga tinggi cenderung menyebar.

Menurut Chatterje dan Hadi tahun 2006, jika terdapat nilai korelasi antar variabel bernilai 0, ma artinya tidak terdapat hubungan yang linier antar variabelnya. Dalam hal ini jika variabel penjelas memiliki nilai korelasi 0 terhadap variabel respon, maka variabel penjelas tersebut tidak bisa diikutsertakan ke dalam model regresi linier. Korelasi antara variabel respon dengan variabel penjelas da korelasi antar variabel penjelas ditunjukkan dengan korelasi Pearson terdapat pada Tabel 2.

Tabel 2. Matriks Korelasi Pearson

\begin{tabular}{|c|c|c|c|c|c|c|c|c|}
\hline & $y$ & $X_{1}$ & $X_{2}$ & $X_{3}$ & $X_{4}$ & $X_{5}$ & $X_{6}$ & $X_{7}$ \\
\hline$X_{1}$ & 0,274 & & & & & & & \\
\hline$X_{2}$ & $-0,006$ & $-0,066$ & & & & & & \\
\hline$X_{3}$ & 0,298 & $-0,022$ & 0,009 & & & & & \\
\hline$X_{4}$ & $-0,108$ & $-0,260$ & $-0,160$ & 0,234 & & & & \\
\hline$X_{5}$ & $-0,071$ & $-0,294$ & 0,092 & 0,048 & 0,271 & & & \\
\hline$X_{6}$ & $-0,004$ & 0,429 & $-0,084$ & $-0,238$ & $-0,297$ & $-0,171$ & & \\
\hline$X_{7}$ & 0,054 & $-0,103$ & 0,076 & 0,169 & 0,275 & 0,369 & $-0,325$ & \\
\hline$X_{8}$ & $-0,124$ & $-0,224$ & 0,091 & 0,084 & 0,475 & 0,125 & $-0,182$ & 0,144 \\
\hline
\end{tabular}

Pada Tabel 2 menunjukkan bahwa ada empat variabel penjelas yang memiliki hubungan positif dengan variabel respon, yaitu variabel $X_{1}, X_{2}$ dan $X_{7}$. Sementara itu, variabel penjelas yang memiliki hubungan negatif dengan variabel respon adalah variabel $X_{3}, X_{4}, X_{5}, X_{6}$ dan $X_{8}$. Semua variabel penjelas memiliki hubungan yang linier terhadap variabel respon, maka semua variabel penjelas diikutsertakan ke dalam proses selanjutnya.

\section{B. Model Regresi Linier Berganda}

Model dugaan regresi linier berganda (full model) adalah:

$$
\begin{gathered}
\hat{Y}=\left(-6.385 \times 10^{-16}\right)+0.149 X_{1}+0.445 X_{2}-0.092 X_{3}-0.089 X_{4}-0.230 X_{5}+0.041 X_{6} \\
+0.380 X_{7}-0.032 X_{8}
\end{gathered}
$$




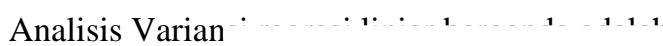

\begin{tabular}{|c|c|c|c|c|}
\hline$\overline{\text { Sumt }}$ & Tabel 3. Analisis V & i $\mathrm{Re}$ & ier $\mathrm{Be}$ & :itung \\
\hline Regresi & 19.141 & 8 & 2.393 & \multirow{2}{*}{6.278} \\
\hline Galat & 6.859 & 18 & 0.381 & \\
\hline Total & 26 & 26 & & \\
\hline
\end{tabular}

Berdasarkan Tabel 3, didapat nilai $F_{\text {hitung }}=6.278>F_{0.05(8 ; 18)}=2.5102$. Jadi dapat disimpulkan bahwa minimal ada satu variabel penjelas yang berpengaruh secara signifikan terhadap variabel respon. Tahap selanjutnya adaah pemilihan model terbaik dengan menggunakan Backward Regression.

Model dugaan regresi terbaik yang terbentuk adalah:

$$
\hat{y}=0.423 X_{2}-0.287 X_{5}+0.513 X_{7}
$$

Pada pengujian asumsi galat model regresi linier berganda didapatkan bahwa galat telah memenuhi asumsi kenormalan namun tidak homogen.

\section{Uji Pengaruh Spasial}

Penyebab adanya ketidakhomogenan ragam pada galat dikhawatirkan akibat dari efek spasial. Oleh karena itu, untuk mengetahui apakah ada pengaruh spasial atau tidak perlu dilakukan uji autokorelasi spasial dan heterogenitas spasial.

\section{Pengujian Autokorelasi Spasial}

Pengujian autokorelasi spasial bertujuan untuk mengidetifikasi apakah ada ketergantungan spasial antar kabupaten/kota terhadap variabel respon atau tidak. Pengujian autokorelasi spasial dilakukan dengan menggunakan uji Moran's I.

Tabel 4. Hasil Uji Moran’s I

\begin{tabular}{|c|c|}
\hline Kode & $|Z(I)|$ \\
\hline$y$ & 0.235 \\
\hline$e$ & 0.382 \\
\hline
\end{tabular}

*Signifikan pada $\alpha=5 \% ; Z_{0,05}=1.96$

Berdasarkan Tabel 4, dapat disimpulkan bahwa tidak terdapat autokorelasi spasial yang signifikan antar lokasi yang diamati dengan lokasi tetangga terkait kasus pneumonia balita di provinsi Jawa Barat. Begitu juga dnegan galat, tidak terdapat ketergantungan galat untuk setiap wilayah amatan.

\section{Pengujian Heterogenitas Spasial}

Pengujian heterogenitas spasial ini bertujuan untuk mengetahui apakah ada keragaman antar wilayah kabupaten/kota atau tidk. Pengujian Heterogenitas spasial dilakukan dengan menggunakan uji Breusch-Pagan.

Tabel 5. Hasil Uji Breusch-Pagan

\begin{tabular}{|c|c|}
\hline Nilai $B P$ & DB \\
\hline 10.634 & 3 \\
\hline
\end{tabular}

Berdasarkan Tabel 5, didapatkan nilai $B P=10.634>F \chi_{3 ; 0.05}^{2}=7.8147$. Artinya, terdapat heterogenitas antar wilayah kabupaten/kota di provinsi Jawa Barat. 


\section{Model GWR}

Proses awal yang dilakukan dalam pemodelan GWR adalah menghitung jarak euclid antar lokasi amatan yang satu dengan yang lain. Kemudian dilaknjutkan dengan perhitungan pembobot untuk setiap amatan dengan menggunakan Fixed Kernel Gaussian dari nilai bandwidth optimum. Pemilihan bandwidth optimum dilakukan dengan proses iterasi berdasarkan besar jarak dengan nilai $\mathrm{CV}$ yang didapatkan.

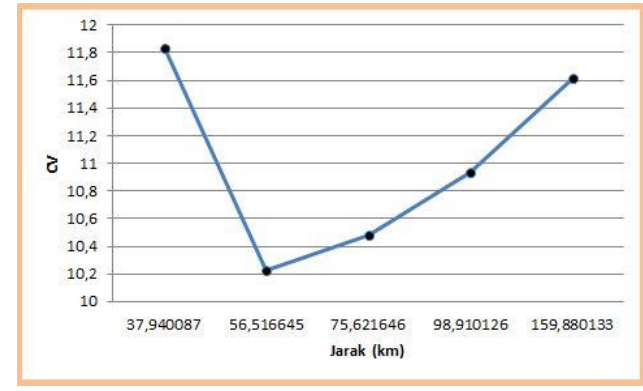

Gambar 2. Diagram untuk Pencarian Bandwidth Optimum

Berdasarkan Gambar 2, hasil bandwidth optimum dari proses iterasi masih dalam satuan km, maka untuk melanjutkan proses berikutnya perlu diubah kedalam satuan derajat bumi yaitu membagi $56.516645 \mathrm{~km}$ dengan $111.319(1$ derajat bumi $=111.319)$ sehingga bandwidth optimum yang didapat sebesar 0.5076999 .

Setelah didapatkan pembobot maka diperoleh pendugaan parameter untuk setiap wilayah. Pada Tabel disajikan nilai minimum dan maksimum dari pendugaan model GWR.

Tabel 6. Nilai Pendugaan Parameter Model GWR

\begin{tabular}{|c|c|c|}
\hline & Minimum & Maksimum \\
\hline Konstanta & -0.247162 & 0.155989 \\
\hline$X_{2}$ & -0.065781 & 0.565394 \\
\hline$X_{5}$ & -0.566454 & 0.016491 \\
\hline$X_{7}$ & 0.376034 & 0.879666 \\
\hline
\end{tabular}

Penduga parameter untuk $X_{2}$ berkisar antara -0.065781 sampai 0.565394 , sedangkan untuk $X_{5}$ berkisar antara -0.566454 sampai 0.016491 serta untuk $X_{7}$ berkisar antara 0.376034 sampai 0.879666 .

Pengujian kebaikan model dilakukan secara simultan dapat dilihat pada Tabel 7.

Tabel 7. Hasil Statistik Uji F model GWR

\begin{tabular}{|c|c|c|c|}
\hline Model & JKG & DB & $F_{\text {hitung }}$ \\
\hline Model OLS & 7.317 & 23 & 2.414 \\
\cline { 1 - 3 } Model GWR & 3.031 & 14.114 & \\
\hline
\end{tabular}

Berdasarkan Tabel 7, didapat nilai $F_{\text {hitung }}=2.414>F_{0.05(23 ; 14.114)}=2.357306$. Jadi dapat disimpulkan bahwa terdapat perbedaan yang signifikan antara model OLS dengan model GWR. Oleh karena itu, model GWR berguna (useful) untuk memodelkan kasus pneumonia balita di provinsi Jawa Barat. 
Variabel yang signifikan dari model GWR berbeda untuk setiap wilayahnya. Hal ini dapat dilihat dari nilai statistik uji $t$ jika variabel penjelas memiliki $\left|t_{\text {hitung }}\right|>F_{0.05 ; 14.114}=2.144787$ maka variabel terkait berpengaruh signifikan terhadap variabel respon.

Tabel 8. Variabel yang Signifikan dalam Model GWR Tiap Kabupaten/Kota di Provinsi Jawa Barat

\begin{tabular}{|l|c|}
\hline \multicolumn{1}{|c|}{ Kabupaten/Kota } & Variabel yang Signifikan \\
\hline $\begin{array}{l}\text { Kab. Ciamis, Kab. Kuningan, Kab. Cirebon, Kab Majalengka, } \\
\text { Kab. Sumedang, Kab. Indramayu, Kab. Pangandaran, } \\
\text { Kota Cirebon }\end{array}$ & $X_{7}$ \\
\hline Kab. Subang & $X_{2}, X_{7}$ \\
\hline Kab. Garut dan Kab. Tasikmalaya & $X_{5}, X_{7}$ \\
\hline Kab. Bogor, Kab. Sukabumi, Kab. Cianjur, Kab. Bandung, & $X_{2}, X_{5}, X_{7}$ \\
\hline $\begin{array}{l}\text { Kab. Purwakarta, Kab. Karawang, Kab. Bekasi, } \\
\text { Kab. Bandung Barat, Kota Bogor, Kota Sukabumi, } \\
\text { Kota Bandung, Kota Bekasi, Kota Depok dan Kota Cimahi }\end{array}$ & $X_{2}, X_{5}, X_{7}$ \\
\hline
\end{tabular}

Model dugan GWR terbaik yang terbentuk adalah:

Tabel 9. Model GWR Tiap Kabupaten/Kota di Provinsi Jawa Barat

\begin{tabular}{|l|l|}
\hline Kabupaten/Kota & \multicolumn{1}{|c|}{ Model GWR } \\
\hline Bogor & $\hat{y}=0.526385 X_{2}-0.455216 X_{5}+0.385583 X_{7}$ \\
\hline Sukabumi & $\hat{y}=0.565394 X_{2}-0.566454 X_{5}+0.376034 X_{7}$ \\
\hline Cianjur & $\hat{y}=0.517228 X_{2}-0.485771 X_{5}+0.410161 X_{7}$ \\
\hline Bandung & $\hat{y}=0.508064 X_{2}-0.558091 X_{5}+0.453304 X_{7}$ \\
\hline Purwakarta & $\hat{y}=0.415226 X_{2}-0.313553 X_{5}+0.444383 X_{7}$ \\
\hline Karawang & $\hat{y}=0.438171 X_{2}-0.322445 X_{5}+0.420243 X_{7}$ \\
\hline Bekasi & $\hat{y}=0.469460 X_{2}-0.361599 X_{5}+0.407472 X_{7}$ \\
\hline Bandung Barat & $\hat{y}=0.406199 X_{2}-0.368197 X_{5}+0.482499 X_{7}$ \\
\hline Kota Bogor & $\hat{y}=0.542003 X_{2}-0.489440 X_{5}+0.378131 X_{7}$ \\
\hline Kota Sukabumi & $\hat{y}=0.554440 X_{2}-0.554783 X_{5}+0.390213 X_{7}$ \\
\hline Kota Bandung & $\hat{y}=0.326388 X_{2}-0.283947 X_{5}+0.528742 X_{7}$ \\
\hline Kota Bekasi & $\hat{y}=0.477997 X_{2}-0.371948 X_{5}+0.404649 X_{7}$ \\
\hline Kota Depok & $\hat{y}=0.526204 X_{2}-0.446589 X_{5}+0.384556 X_{7}$ \\
\hline Kota Cimahi & $\hat{y}=0.395776 X_{2}-0.353584 X_{5}+0.487139 X_{7}$ \\
\hline Garut & $\hat{y}=-0.250924 X_{5}+0.561662 X_{7}$ \\
\hline Tasikmalaya & $\hat{y}=-0.359405 X_{5}+0.509266 X_{7}$ \\
\hline Subang & $\hat{y}=0.322343 X_{2}+0.492626 X_{7}$ \\
\hline Ciamis & $\hat{y}=0.558184 X_{7}$ \\
\hline Kuningan & $\hat{y}=0.694041 X_{7}$ \\
\hline Cirebon & $\hat{y}=0.839784 X_{7}$ \\
\hline Majalengka & $\hat{y}=0.689448 X_{7}$ \\
\hline Sumedang & $\hat{y}=0.690277 X_{7}$ \\
\hline Indramayu & $\hat{y}=0.879666 X_{7}$ \\
\hline Pangandaran & $\hat{y}=0.512876 X_{7}$ \\
\hline Kota Cirebon & $\hat{y}=0.821968 X_{7}$ \\
\hline Kota Tasikmalaya & $\hat{y}=0.554804 X_{7}$ \\
\hline Kota Banjar & $\hat{y}=0.558963 X_{7}$ \\
\hline & \\
\hline
\end{tabular}


Secara keseluruhan mode GWR yang terbentuk untuk variabel $X_{2}$ bernilai positif, hal ini mengartikan bahwa semakin tinggi jumlah penderita balita gizi buruk maka semakin tinggi jumlah penderita pneumonia balita di provinsi Jawa Barat. Begitu juga untuk $X_{7}$ bernilai positif, artinya semakin tinggi jumlah puskesmas maka semakin tinggi jumlah penderita pneumonia balita yang terdeteksi untuk setiap wilayah kabupaten/kota. Sedangkan untuk variabel $X_{5}$ bernilai negatif, artinya semakin tinggi persentasi bayi yang diimunisasi dasar lengkap maka semakin rendah jumlah penderita pneumonia balita di provinsi Jawa Barat.

\section{E. Perbandingan Model GWR dengan Model OLS}

Model GWR kasus pneumonia balita di provinsi Jawa Barat yang terbentuk merupakan model yang lebih baik dibandingkan dengan model regresi linier berganda. Hal tersebut dapat dilihat pad Tabel.

Tabel 10. Perbandingan Nilai JKG, $R^{2}$ dan AIC

\begin{tabular}{|c|c|c|c|}
\hline Model & JKG & $R^{2}$ & AIC \\
\hline Model GWR & 3.031 & $88.34 \%$ & 27.722 \\
\hline Model OLS & 7.317 & $71.86 \%$ & 51.371 \\
\hline
\end{tabular}

Berdasarkan Tabel 10, JKG dan nilai AIC dari model GWR berturut-turut bernilai 3.031 dan 27.722 lebih kecil dari model regresi linier berganda yaitu 7.317 dan 51.271 serta nilai $R^{2}$ dari model GWR $(88.34 \%)$ lebih besar dari model regresi linier berganda $(71.86 \%)$. Hal ini menunjukkan bahwa model GWR lebih baik dalam menerangkan keragaman dari kasus pneumonia balita di provinsi Jawa Barat.

\section{PENUTUP}

A. Kesimpulan

1. Data yang digunakan dalam pemodelan mengandung pengaruh spasial sehingga dilakukan pemodelan GWR dengan perhitungan pembobot menggunakan Fixed Kernel Gaussian. Berdasarkan hasil pemodelan dengan GWR diperoleh model yang berbeda-beda untuk setiap wilayah kabupaten/kota di provinsi Jawa Barat.

2. Model Geographically Weighted Regression (GWR) lebih baik daripada model regresi linier berganda dalam memodelkan kasus pneumonia pada balita untuk setiap wilayah kabupaten/kota di provinsi Jawa Barat. Model GWR mampu menerangkan keragaman kasus pneumonia balita sebesar $88.34 \%$ dengan jumlah kuadrat galat 3.031 dan nilai AIC sebesar 27.722, sedangkan model regresi linier berganda mampu menerangkan keragaman kasus pneumonia pada balita lebih rendah dari GWR sebesar $71.86 \%$ dengan jumlah kuadrat galat 7.317 dan nilai AIC sebesar 51.371.

3. Secara umum terdapat tiga faktor yang secara signifikan $(\alpha=5 \%)$ mempengaruhi jumlah penderita pneumonia pada balita di provinsi Jawa Barat yaitu jumlah balita gizi buruk $\left(X_{2}\right)$, persentase bayi yang diimunisasi dasar lengkap $\left(X_{5}\right)$ dan jumlah puskesmas $\left(X_{7}\right)$.

\section{B. Saran}

1. Upaya yang dapat dilakukan untuk mengurangi jumlah kasus pneumonia di provinsi Jawa Barat adalah dengan meningkatkan penyebaran pelayanan imunisasi bayi di setiap kabupaten/kota di provinsi Jawa Barat serta menurunkan tingkat kasus balita gizi buruk dan juga salah satu upaya lain yang perlu dilakukan adalah menambah fasilitas pelayanan kesehatan seperti puskesmas di setiap kabupaten/kota.

2. Penelitian ini dapat dilanjutkan dengan menggunakan metode Mixed Geoghraphically Weighted Regression (MGWR).

\section{Daftar Pustaka}

Anselin, Luc. 1988. Spatial Econometrics: Methods and Models. The Netherlands: Kluwer Academic Publishers.

Anwar, Athena., dan Dharmayanti, Ika. "Pneumonia pada Anak Balita di Indonesia", Jurnal Kesehatan Masyarakat Nasional Vol. 8 No. 8. 2014 
Baharudin., Suhariningsih., dan Ulama, Brodjol Sutijo Suprih. "Geographically Weighted Regression Modeling for Analyzing Spatial Heterogeneity on Relationship between Dengue Hemorrhagic Fever Incidence and Rainfall in Surabaya, Indonesia”, Journal of Modern Applied Science Vol.8 No. 3 ISSN: 1913-1844 E-ISSN: 1913-1852. 2014

BPS. 2015. Data dan Informasi Kemiskinan Kabupaten/Kota Tahun 2014. Jakarta: Badan Pusat Statistik.

BPS. 2013. Pengembangan Model Sosial Ekonomi: Penggunaan Metode GWR untuk Analisis Data Sosial dan Ekonomi. Jakarta: Badan Pusat Statistik.

Dinkes. 2015. Profil Kesehatan Provinsi Jawa Barat Tahun 2014. Bandung: Dinas Kesehatan Provinsi Jawa Barat.

Fischer, Manfred M dan Wang, Jinferd. 2011. Spatial Data Analysis: Models, Methods, and Techniques. New York: Springer

Fotheringham, A. Stewart., Brundson, Chris., dan Charlton, Martin. 2002. Geographically Weighted Regression The Analysis Of Spatially Varying Relationships. UK: John Wiley \& Sons, LTD.

Gujarati, D.N. 2003. Basic Econometric. Edisi ke-4. Mc. New York: Graw Hill Companies.

IVAC. 2014. Pneumonia and Diarrhea Progress Report 2014. Maryland: Johns Hopkins Bloomberg School of Public Health.

IVAC. 2015. Pneumonia and Diarrhea Progress Report 2015. Maryland: Johns Hopkins Bloomberg School of Public Health.

Kemenkes RI. 2015. Profil Kesehatan Indonesia Tahun 2014. Jakarta: Kementrian Kesehatan RI.

Myers, Raymond H., dan Milton, Janet S. 2011. A First Course In The Theory of Linear Statistical Models. Boston: PWS-KENT Publishing Company.

Said, Mardjanis. "Pengendalian Pneumonia Anak-Balita dalam Rangka Pencapaian MDG4", Buletin Jendela Epidemiologi Vol.3 ISSN: 2087-1546. 2010

Sinaga, Kristina Pestaria. "Proverty Data Modeling in North Sumatera Province Using Geographically Weighted Regression (GWR) Method", International Journal of Science and Research (IJSR) Vol 4 Issue 2 ISSN(Online): 2319-7064. 2015

Suyono. 2015. Analisis Regresi untuk Penelitian. Yogyakarta: Deepublish.

Zayinur R, M Reza. 2013. "Lama Hari Rawat Pasien Ventilator Associated Penumonia Pada Pasien dengan Ventilator Mekanik di ICU RSUP Dr. Kariadi”. Karya Tulis Ilmiah. Semarang: Universitas Diponegoro. 